\title{
Bornova Ekolojik Koşullarında Bazı Anason Hatlarının Verim ve Kalite Özelliklerinin Belirlenmesi Üzerine Bir Ön Çalışma
}

\section{A Preliminary Study on Determination of Yield and Quality Characteristics of Some Anise Lines in Bornova Ecological Conditions}

\section{Mehmet Fatih ÇAKIR ${ }^{1^{*}}$ \\ Emine BAYRAM ${ }^{2}$}

${ }^{1}$ Düzce Üniversitesi Çevre ve Sağlık

Teknolojilerinde İhtisaslaşma Koordinatörlüğü, Düzce

${ }^{1}$ Ege Üniversitesi Ziraat Fakültesi Tarla Bitkileri Bölümü, İzmir

Sorumlu yazar: mehmetfatihcakir@duzce.edu.tr

0000-0003-1354-9476

0000-0001-5856-2637

Destekleyen Kurum :Ege Üniversitesi Bilimsel Araştırma Projeleri Koordinasyon Birimi

Proje Numaras1 $\quad$ :18-ZRF-018

Gönderilme Tarihi:

Kabul Tarihi
23 Ağustos 2020

15 Kasim 2020

\section{ÖZET}

$\mathrm{Bu}$ araştırmada, Bornova ekolojik koşullarında seçilmiş anason hatlarının bazı verim ve kalite özelliklerinin belirlenmesi amaçlanmıştır. Deneme, Tesadüf Blokları Deneme Desenine göre dört tekerrürlü olarak Ege Üniversitesi Ziraat Fakültesi, Tarla Bitkileri Bölümü deneme alanında, 2017 yılı yetiştirme döneminde yürütülmüş̧ür. Çalışmada bitki materyali olarak, dört farklı kökenli (İspanya, Mısır, Suriye, Türkiye) 11 adet hat kullanılmıştır. Araştırmada, anason hatlarında bitki boyunun 42.00-49.00 cm, bitkide dal sayısının 5.25-8.75 adet/bitki, meyveli dal sayısının 5.02-6.22 adet/bitki, şemsiye sayısının 6.50-11.00 adet/bitki, bin tane ağırlığının $3.00-4.00 \mathrm{~g}$, biyolojik veriminin $184.50-270.25 \mathrm{~kg} / \mathrm{da}$, tohum veriminin $77.62-110.83 \mathrm{~kg} / \mathrm{da}$, hasat indeksinin \%36.5-47.5, uçucu yağ oranının \%2.00-3.00 aralığında değiştiği tespit edilmiştir. Agronomik ve verim özellikleri bakımından Özel sektör-164, Özel sektör-150 ve Çeşme31 hatları, uçucu yağ oranı bakımından ise Çavdır-10 ve Tefenni-177 hariç incelenen tüm hatlar en yüksek değerlere sahip olmuşlardır.

Anahtar kelimeler: Pimpinella anisum, anason, hat, tohum verimi, uçucu yağ. 


\section{ABSTRACT}

Present research was conducted to determine some agronomic and technological properties of selected anise lines in Bornova ecological conditions. Randomized complete block design was used with four replications in the research area of Department of Field Crops, Faculty of Agriculture, Ege University in 2017. As the material, selected eleven anise lines of four different origins (Spain, Egypt, Syria, Turkey) were used. In current research; plant height (42.00-49.00 cm), number of branches/plant (5.25-8.75), number of fruit branches/plant (5.02-6.22), number of umbel/plant (6.50-11.62), 1000-seed weight (3.00-4.00 g), biological yield $(184.50-270.25 \mathrm{~kg} / \mathrm{da})$, seed yield (77.62-110.82 $\mathrm{kg} / \mathrm{da})$, harvest index (36.5-47.5\%) and essential oil ratio (2.00-3.00\%) were determined. Highest values for all agronomic and yield attributes were shown by three lines Özel Sektör-164, Özel Sektör-150 and Çeşme-31. Whereas in terms of essential oil ratio, all the lines examined, except Çavdır-10 and Tefenni-177, had the highest values.

Keywords: Pimpinella anisum, anise, line, seed yield, essential oil.

\section{GİRIŞ}

Apiaceae familyasından olan anason (Pimpinella anisum L.), beyaz çiçekli, tek yıllık ve otsu bir bitkidir. Bitki boyu 30-50 cm civarındadır, çiçekleri şemsiye şeklinde olup, meyveleri 3-6 mm uzunlukta ve 1-3 mm genişlikte, ters armut biçiminde, kısa saplı, gri-yeşil ya da yeşilimsisarı renkli ve üzeri tüylüdür (Orav ve ark., 2008; Shojaii ve Fard, 2012).
Anason tohumlarında \%1.5-5.0 uçucu yağ, \%10-20 sabit yağ, \%18 protein bulunmaktadır. En önemli uçucu yağ bileşeni trans-anethol (\%80-90)'dur (Akgül, 1993). Trans-anethol anasonun kendine özgü kokusunu verir. Tatlımsı tat da bu maddeden kaynaklanır. Anasona koku veren, fakat acı olan diğer bir madde de methyl chavicol'dür (Ceylan, 1997).

Uçucu yağı antioksidan, antispazmodik, antimikrobiyal, insekdisidal ve antifungal özelliklere sahiptir (Tirapelli ve ark., 2007). Tıbbi olarak nezle tedavisinde, dispeptik şikâyetlerde ve hafif balgam söktürücü olarak kullanılır (Blumenthal, 1999). Anason eczacilık, parfüm, gıda ve içecek endüstrilerinde kullanılan önemli bir baharat ve tıbbi bir bitkidir.

Anason, sahip olduğu aroma ve tedavi edici özelliğinden dolayı ticari önem taşımaktadır. Yurdumuzda anason üretimi ve ekim alanları y1llara göre değişmekle birlikte genellikle Afyon, Antalya, Burdur, Denizli, Balıkesir, Bursa, Isparta, İzmir, Kütahya ve Muğla illerimiz sınırları içinde yetiştirilmekte olup anason ekiliş alanı, üretim miktarı ve verimi çok değişik faktörlerin etkisi ile stabil değildir (Bayram, 2019). Anason tarımının gelişmeyişi ve üretimin düşük olmasının nedenleri; anasonda üretimin popülasyon halinde olmas1, çiftçinin kalitesi yüksek ve verimli sertifikalı tohumluk bulamaması, üretimin genelde küçük aile işletmeciliği şeklinde yapılması, üretim tekniği, gübrelemesi ve zirai mücadelesi gibi konularda yeteri kadar bilgiye sahip olmamas1, anason alım fiyatlarının düşük olması ve yıllara göre karlılığın değişmesi şeklinde sıralanabilir 
(Bayram, 1992). Ülkemizde ihracat potansiyeli yüksek olan anason bitkisinde henüz istenilen seviye ulaşılamamıştır. Anason bitkisinde yüksek verimli ve istenilen kaliteye sahip çeşitlerin geliştirilmesi, uygun ekolojik koşullarda yetiştirilmesi ve yetiştirme tekniklerinin belirlenmesi üretim miktarında artışa ve ticaret hacminde gelire katkı sağlayacaktır.

$\mathrm{Bu}$ çalışmada, ekonomik değeri yüksek olan ve bölgeye uyum sağlayabilecek Üniversite-Özel sektör işbirliği ile geliştirilen farklı kökenli bazı anason hatlarının Bornova ekolojik koşullarında verim ve kalite özelliklerinin belirlenmesi amaçlanmıştır.

\section{MATERYAL VE YÖNTEM}

Bu araştırma, E. Ü. Ziraat Fakültesi Tarla Bitkileri Bölümü Uygulama ve Araştırma alanında yürütülmüştür. Çalışmada bitki materyali olarak, dört farklı orijinli (İspanya, Mısır, Suriye, Türkiye) seçilmiş 11 adet hat kullanılmıştır (Çizelge 1).

Çizelge 1. Denemede kullanılan anason hatlarının orijinleri

\begin{tabular}{ll}
\hline Hat No & Popülasyon Kökeni \\
\hline 10 & Çavdır (Denizli-Türkiye) \\
31 & Çeşme (İzmir-Türkiye) \\
49 & Suriye \\
51 & Suriye \\
85 & Fethiye (Muğla-Türkiye) \\
146 & Özel Sektör \\
150 & Özel Sektör \\
164 & Özel Sektör \\
168 & Misır \\
177 & Tefenni (İspanya) \\
213 & Madrid (İspanya) \\
\hline
\end{tabular}

Denemenin yürütüldüğü 2017 yılının OcakTemmuz ayları ortalama sicaklık $17.8{ }^{\circ} \mathrm{C}$ olup, toplam yağış miktarı $408.3 \mathrm{~mm}$ olarak gerçekleşmiştir. Uzun yıllar sıcaklık ortalaması $\left(18.1^{\circ} \mathrm{C}\right)$ ve toplam yağış $(406 \mathrm{~mm})$ değerleri ile benzerlik göstermektedir (Çizelge 2).

Deneme alanı, 0-20 cm derinliğinde milli-kil bünyeli, 20-40 cm derinliğinde ise killi-tınlı bünyeye sahiptir. Deneme alanı yüzeyinin $\mathrm{pH}$ 's1 8.2 olup orta alkali iken, $20-40 \mathrm{~cm}$ derinliğinde $\mathrm{pH}=7.8$ değeri ile hafif alkali tepkimeli özelliğine ve düşük organik madde oranına sahip topraklardan oluşmaktadır (Çizelge 3).

Deneme, tesadüf blokları deneme desenine göre, 4 tekrarlamalı olarak kurulmuş, 31 Ocak 2017 tarihinde ekim yapılmıştır. Parsel boyutları $1.2 \times 3.0 \mathrm{~m}$, sira aras $140 \mathrm{~cm}$ ve bloklar arası mesafe $1 \mathrm{~m}$ olarak belirlenmiştir. Tohum ekimleri her parselde 3 sıra olacak şekilde dekara $2 \mathrm{~kg}$ tohum hesabıyla gerçekleştirilmiştir.

Araştırmada $4 \mathrm{~kg} / \mathrm{da} \mathrm{N}$ ve $4 \mathrm{~kg} / \mathrm{da} \mathrm{P}_{2} \mathrm{O}_{5}$ gübresi uygulanmıştır. Yabancı ot mücadelesi; tohum çıkışı sonrası iki kez, çiçeklenme dönemi ve hasat öncesi dönemlerinde birer kez çapalama işlemi ile yürütülmüştür. Sulama işlemi 3 defa yapılmıştır (bitkiler 10-15 cm boylandığında, çiçeklenme başlangıcında ve tohum bağlama döneminde). Hasat işlemi meyvelerin kahverengileştiği dönemde (Temmuz ortası) gerçekleştirilmiştir. Çalışmada bitki boyu (cm), dal sayısı (adet/ bitki), meyveli dal sayısı (adet/bitki), şemsiye sayısı (adet/bitki), bin tane ağırlığı (g), biyolojik 
Çizelge 2. Araştırma yerine ait bazı iklim verileri (Anonim, 2017)

\begin{tabular}{lcccc}
\hline \multirow{2}{*}{ Aylar } & \multicolumn{2}{c}{ Sicaklık $^{\circ} \mathbf{C}$} & \multicolumn{2}{c}{ Yağiş (mm) } \\
\cline { 2 - 5 } & $\mathbf{2 0 1 7}$ & UYO & $\mathbf{2 0 1 7}$ & UYO \\
\hline Ocak & 6.3 & 8.8 & 235.7 & 165.1 \\
Şubat & 10.4 & 11.2 & 55.6 & 74.9 \\
Mart & 13.3 & 13.3 & 72.5 & 69.8 \\
Nisan & 16.6 & 16.9 & 15.7 & 35.7 \\
Mayıs & 21.7 & 21.9 & 27.0 & 40.1 \\
Haziran & 26.5 & 26.0 & 1.8 & 19.8 \\
Temmuz & 29.8 & 29.1 & 0.0 & 0.6 \\
X- $\Sigma$ & 17.8 & 18.1 & 408.3 & 406 \\
UYO: Uzun yillar ortalamas1 & & & &
\end{tabular}

Çizelge 3. Deneme alanı toprağının bazı fiziksel ve kimyasal toprak özellikleri

\begin{tabular}{ccc}
\hline Toprak Derinliği (cm) & $\mathbf{0 - 2 0} \mathbf{~ c m}$ & $\mathbf{2 0 - 4 0 \mathbf { c m }}$ \\
\hline Kum (\%) & 24.72 & 32.72 \\
Kil (\%) & 32.56 & 30.56 \\
Mil (\%) & 42.72 & 36.72 \\
N (\%) & 0.101 & 0.123 \\
P(ppm) & 0.4 & 0.4 \\
K (ppm) & 400 & 300 \\
Ca (ppm) & 5400 & 5100 \\
Na (ppm) & 20 & 20 \\
Fe (ppm) & 13.6 & 16.2 \\
OM (\%) & 1.130 & 1.150 \\
$\mathbf{p H}$ & 8.2 & 7.8 \\
\hline a:Organik madde & &
\end{tabular}

verim $(\mathrm{kg} / \mathrm{da})$, tohum verimi $(\mathrm{kg} / \mathrm{da})$, hasat indeksi (\%) ve uçucu yağ oranı (\%) gibi özellikler incelenmiştir. Uçucu yağ oranı, Clevenger cihazı ile volümetrik olarak belirlenmiştir (Wichtl, 1971). Araştırılan her bir özellik için elde edilen veriler, Tarist istatistik paket programı (Açıkgöz ve ark., 1994) kullanılarak, tesadüf blokları deneme desenine göre varyans analizleri yapılmış, önemli çıkan özellikler, LSD değerlerine göre gruplandırılmıştır.

\section{BULGULAR VE TARTIŞMA}

Bornova ekolojik koşullarında yetiştirilen anason hatlarına ait incelenen özelliklerin varyans analiz sonuçları, Çizelge 4'te; incelenen özelliklerin ortalama değerleri ise Çizelge 5'de sunulmuştur.

\section{Bitki Boyu}

Hatlara ilişkin bitki boyu ortalamaları istatistiki açıdan \%5 düzeyinde önemli bulunmuştur. Anason hatlarının bitki boyu ortalaması 42.00$49.00 \mathrm{~cm}$ arasında değiştiği gözlemlenmiştir. En uzun bitki boyu değerlerine sahip grubu 
Çizelge 4. İncelenen özelliklerin varyans analiz sonuçları (F değeri)

\begin{tabular}{|c|c|c|c|c|c|c|c|c|c|c|}
\hline VK & SD & $\begin{array}{l}\text { Bitki } \\
\text { boyu } \\
(\mathrm{cm})\end{array}$ & $\begin{array}{c}\text { Dal Sayısı } \\
\text { (adet/bitki) }\end{array}$ & $\begin{array}{c}\text { Meyveli } \\
\text { Dal Sayısı } \\
\text { (adet/bitki) }\end{array}$ & $\begin{array}{c}\text { Şemsiye } \\
\text { Sayısı } \\
\text { (adet/bitki) }\end{array}$ & $\begin{array}{c}\text { Bin } \\
\text { Tane } \\
\text { Ağırlı̆ğ } \\
(\mathbf{g}) \\
\end{array}$ & $\begin{array}{c}\text { Biyolojik } \\
\text { Verim (kg/ } \\
\text { da) }\end{array}$ & $\begin{array}{l}\text { Tohum } \\
\text { Verimi } \\
(\mathrm{kg} / \mathrm{da})\end{array}$ & $\begin{array}{c}\text { Hasat } \\
\text { İndeksi } \\
(\%) \\
\end{array}$ & $\begin{array}{l}\text { Uçucu } \\
\text { Yağ } \\
\text { Oranı } \\
(\%)\end{array}$ \\
\hline Tekerrür & 3 & $33.659^{*}$ & 2.000 & $2.629 \mathrm{~ns}$ & $10.083 \mathrm{~ns}$ & $0.273 \mathrm{~ns}$ & $1923.545 \mathrm{~ns}$ & $270.144 \mathrm{~ns}$ & $72.078 \mathrm{~ns}$ & $0.023 \mathrm{~ns}$ \\
\hline Hat & 10 & $20.391 *$ & $6.023 * *$ & $0.668 \mathrm{~ns}$ & $6.255 \mathrm{~ns}$ & $0.455^{* *}$ & 2633.414* & $419.623 \mathrm{~ns}$ & $56.527 \mathrm{~ns}$ & $0.523^{*}$ \\
\hline Hata & 30 & 9.542 & 1.617 & 1.062 & 4.200 & 0.139 & 995.062 & 396.344 & 49.724 & 0.189 \\
\hline Genel & 43 & & & & & & & & & \\
\hline
\end{tabular}

*:\% 5 düzeyinde önemli , **:\%1 düzeyinde önemli, ns: önemsiz, VK:Varyasyon Kaynakları SD: Serbestlik derecesi

Çizelge 5. İncelenen özelliklerin ortalama değerleri

\begin{tabular}{|c|c|c|c|c|c|c|c|c|c|}
\hline Hatlar & $\begin{array}{l}\text { Bitki Boyu } \\
(\mathrm{cm})\end{array}$ & $\begin{array}{l}\text { Dal } \\
\text { Sayısı } \\
(\mathrm{cm}) \\
\end{array}$ & $\begin{array}{l}\text { Meyveli } \\
\text { Dal Sayısı } \\
\text { (adet/bitki) }\end{array}$ & $\begin{array}{l}\text { Şemsiye } \\
\text { Sayısı } \\
\text { (adet/bitki) }\end{array}$ & $\begin{array}{l}\text { Bin Tane } \\
\text { Ağırlığı } \\
\text { (g) }\end{array}$ & $\begin{array}{l}\text { Biyolojik } \\
\text { Verim (kg/ } \\
\text { da) }\end{array}$ & $\begin{array}{l}\text { Tohum } \\
\text { Verimi } \\
\text { (kg/da) }\end{array}$ & $\begin{array}{l}\text { Hasat } \\
\text { İndeksi } \\
(\%)\end{array}$ & $\begin{array}{l}\text { Uçucu } \\
\text { yağ oranı } \\
(\%)\end{array}$ \\
\hline Çavdır-10 & $44.50^{\mathrm{bcd}}$ & $6.50^{\mathrm{abc}}$ & 5.00 & 7.30 & $3.70^{\mathrm{ab}}$ & $214.00^{\mathrm{cd}}$ & 87.10 & 40.50 & $2.00^{\mathrm{b}}$ \\
\hline Çeşme-31 & $44.00^{\mathrm{bcd}}$ & $6.00^{\mathrm{cd}}$ & 5.10 & 7.70 & $3.20^{\mathrm{bc}}$ & $270.20^{\mathrm{a}}$ & 104.90 & 39.00 & $2.75^{\mathrm{ab}}$ \\
\hline Suriye-49 & $43.50^{\mathrm{bcd}}$ & $5.50^{\mathrm{d}}$ & 5.00 & 7.30 & $3.50^{\mathrm{abc}}$ & $214.70^{\mathrm{cd}}$ & 91.20 & 42.50 & $2.25^{\mathrm{ab}}$ \\
\hline Suriye-51 & $45.00^{\mathrm{a}-\mathrm{d}}$ & $7.20^{\mathrm{abc}}$ & 5.50 & 7.30 & $3.00^{\mathrm{d}}$ & $257.50^{\mathrm{abc}}$ & 99.80 & 38.75 & $2.75^{\mathrm{ab}}$ \\
\hline Fethiye-85 & $42.00^{\mathrm{d}}$ & $5.20^{\mathrm{d}}$ & 5.00 & 6.50 & $3.20^{\mathrm{bc}}$ & $214.20^{\mathrm{cd}}$ & 101.60 & 47.50 & $2.50^{\mathrm{ab}}$ \\
\hline Özel Sektör-146 & $46.70^{\mathrm{abc}}$ & $5.20^{\mathrm{d}}$ & 5.50 & 8.00 & $3.00^{\mathrm{d}}$ & $184.50^{\mathrm{d}}$ & 77.60 & 40.50 & $3.00^{\mathrm{a}}$ \\
\hline Özel Sektör-150 & $46.00^{\mathrm{a}-\mathrm{d}}$ & $8.00^{\mathrm{ab}}$ & 5.60 & 8.00 & $3.00^{\mathrm{d}}$ & $224.20^{\mathrm{bcd}}$ & 106.00 & 47.50 & $2.25^{\mathrm{ab}}$ \\
\hline Özel Sektör-164 & $47.20^{\mathrm{ab}}$ & $8.00^{\mathrm{ab}}$ & 6.10 & 9.60 & $3.20^{\mathrm{bc}}$ & $242.70^{\mathrm{abc}}$ & 110.80 & 45.00 & $2.25^{\mathrm{ab}}$ \\
\hline Misır-168 & $42.50^{\mathrm{cd}}$ & $8.70^{\mathrm{a}}$ & 6.20 & 11.00 & $3.00^{\mathrm{d}}$ & $262.00^{\mathrm{ab}}$ & 99.30 & 38.50 & $2.50^{\mathrm{ab}}$ \\
\hline Tefenni-177 & $49.00^{\mathrm{a}}$ & $7.20^{\mathrm{abc}}$ & 5.10 & 7.50 & $3.50^{\mathrm{abc}}$ & $237.20^{\mathrm{abc}}$ & 100.90 & 43.00 & $2.00^{\mathrm{b}}$ \\
\hline Madrid-213 & $42.20^{\mathrm{d}}$ & $6.50^{\mathrm{abc}}$ & 5.30 & 8.40 & $4.00^{\mathrm{a}}$ & $246.00^{\mathrm{abc}}$ & 89.50 & 36.50 & $3.00^{\mathrm{a}}$ \\
\hline Ortalama & 44.70 & 6.70 & 5.40 & 8.00 & 3.30 & 233.30 & 97.10 & 41.70 & 2.40 \\
\hline LSD (\%) & $4.46^{*}$ & $2.478 * *$ & ns & ns & $0.728 * *$ & $45.548^{*}$ & ns & ns & $0.84^{*}$ \\
\hline CV $(\%)$ & 6.91 & 20.2 & 20.04 & 23.8 & 11.26 & 13.52 & 20.50 & 16.8 & 17.6 \\
\hline
\end{tabular}

Suriye-51, Özel Sektör-146, Özel Sektör-150, Özel Sektör-164, Tefenni-177 hatları, en kısa bitki boyu değerlerine sahip grubu ise Çavdır-10, Çeşme-31, Suriye-49, Suriye-51, Fethiye-85, Özel Sektör-150, Misır-168, Madrid-213 hatları oluşturmuşlardır (Çizelge 5).

Bornova ekolojik koşullarında, anason ile ilgili farklı araştırmacılar tarafından yürütülen bazı çalışmalarda; bitki boyunun 36.10-51.40 $\mathrm{cm}$ arasında değiştiği bildirilmiştir (Bayram,
1992; Boztaş; 2018; Sönmez, 2018). İpek ve ark. (2004), Ankara ekolojik koşullarında bitki boyunu 44.7-50.2 cm, Dağıstanlığlu ve ark. (2009) Göller yöresinde bitki boyunu 30.5-41.07 cm, Yıldırım (2010) Tekirdağ koşullarında bitki boyunu 33.73-39.73 $\mathrm{cm}$ arasında değiştiğini belirlemişlerdir.

Araştırmada elde ettiğimiz bulgular; Bayram (1992), Boztaş (2018), Sönmez (2018), ve İpek ve ark. (2004)'nın bildirdikleri değerlerle 
benzerlik göstermiştir. Dağıstanoğlu ve ark. (2009) ve Yildırım (2010)'in elde ettikleri bulgulardan daha yüksek çıkmıştır. Araştırmalar sonucu bitki boyunda görülen farklılıkların, ekolojik koşullar, kullanılan tohum materyalleri ve uygulanan yetiştirme tekniklerinden dolayı kaynaklanabileceği düşünülmektedir.

\section{Dal Sayısı}

Anason hatlarının dal sayısına ait değerler incelendiğinde, istatistiksel bakımdan \%1 düzeyinde önemli farklılık ortaya çıkmıştır. Anason hatlarında en az dal sayısına sahip grubu Suriye-49, Fethiye-85, Özel sektör-146 ve Cesme-31 hatlarında, en fazla dal sayısına sahip grubu ise Çavdır-10, Suriye-51, Özel Sektör-150, Özel Sektör-164, Misır-168, Tefenni-177, Madrid-213 hatları oluşturmuştur. Ortalama dal sayısı değeri 6.70 adet/bitki olarak bulunmuştur (Çizelge 5).

Bornova ekolojik koşullarında yürüttükleri çalışmalarda anasonda dal sayısını; Bayram (1992) 6.50-7.90 adet/bitki, Sönmez (2018) 6.07.2 adet/bitki, Boztaş (2018) 6.20-8.80 adet/bitki arasında değiştiğini belirtmişlerdir. İpek ve ark., (2004), Ankara ekolojik koşullarında dal sayısını 5.60-7.20 adet/bitki, Dağıstanlığlu ve ark., (2009) Göller Bölgesi'nde dal sayısını 5.806.67 adet/bitki, Doğan ve ark. (2018) Isparta koşullarında dal sayısını 3.30-4.56 adet/bitki arasında değiştiğini bildirmişlerdir.

Araştırma sonucunda elde ettiğimiz sonuçlar; Bayram (1992), Sönmez (2018), Boztaş (2018), Dağıstanlıŏlu ve ark. (2009), İpek ve ark. (2004)'nın sonuçları ile benzerlik göstermiş,
Doğan ve ark. (2018)'1n bildirdiği değerlerden daha yüksek çıkmıştır. Dal sayısında görülen bu farklılıkların; tohum materyallerinin özellikleri ve ekolojik koşulların neden olabileceği tahmin edilmektedir.

\section{Meyveli Dal Sayısı}

Bornova ekolojik koşullarında yetiştirilen anason hatlarının meyveli dal sayısı açısından ortalamaları arasında istatistiki olarak önemli bir farklılık bulunmamıştır (Çizelge 5). Araştırma sonucu meyveli dal sayısına ilişkin elde ettiğimiz değerler 5.02-6.22 adet/bitki arasında değişmiştir. En yüksek meyveli dal sayısına Misır-168 (6.20 adet/bitki) hattı, en düşük meyveli dal sayısına ise Fethiye-85, Çavdır-10 ve Fethiye-85 (5.00 adet/bitki) hatları ulaşmıştır.

Bornova iklim koşullarında; Bayram (1992), meyveli dal sayısını 4.80-5.50 adet/bitki, Boztaş (2018) meyveli dal sayısını 4.70-7.20 adet/bitki arasında değiştiğini bildirmişlerdir. Arslan ve ark. (1999), Ankara koşullarında meyveli dal sayısının 3.00-5.23 adet/bitki, Aksin (2000) Diyarbakır koşullarında meyveli dal sayısının 2.00-6.80 adet/bitki arasında değiştiğini belirtmişlerdir.

Meyveli dal sayısına ait elde ettiğimiz bulgular; Bayram (1992) ve Arslan ve ark. (1999) bildirdikleri alt sınır değerlerinden yüksek, üst sınır değerleriyle uyumlu, Aksin (2000) ve Boztaş (2018)'ın bildirdikleri alt sınır değerlerinden yüksek, üst sınır değerlerinden düşük bulunmuştur.

Araştırma sonuçları ile diğer çalışmalardan elde 
edilen meyveli dal sayısında görülen farkl1lıkların araştırma materyallerinin farklı olması, çalışma yapılan lokasyonların farklı bölgelerde bulunması ve yetiştirme tekniklerinden kaynaklanabileceği tahmin edilmektedir.

\section{Şemsiye Sayısı}

Varyans analiz tablosu incelediğinde hatların ortalamaları arasında istatiksel olarak önemli bir farklılık bulunmamıştır. Çalışmada yer alan anason hatlarına ait şemsiye sayısı 6.50-11.00 adet/bitki arasında değiştiği görülmektedir. En az şemsiye sayısı Fethiye- 85 hattında (6.50 adet/ bitki), en fazla şemsiye sayısı Mısır-168 hattında (11.00 adet/bitki) elde edilmiştir (Çizelge 4).

Anasonda şemsiye sayısına (adet/bitki) ait daha önceki çalışmalarda; Akkan (2016), Edirne ekolojik koşullarında, en düşük 6.72 adet/bitki, en yüksek 11.62 adet/bitki; Bütün (2016), Tekirdağ koşullarında, en yüksek 10.95 adet/bitki, en düşük 7.04 adet/bitki olarak bildirmişlerdir. Şemsiye sayısına ait elde ettiğimiz bulgular belirtilen çalışma sonuçları ile uyum sağlamaktadır. Doğan ve ark. (2018), Isparta koşullarında, 2.90-4.30 adet/bitki; Aksin (2000) Diyarbakır ekolojik koşullarında, 1.30-8.50 adet/bitki arasında değiştiğini belirtmişlerdir. Bizim araştırma bulgularımız, bu sonuçlardan daha yüksek çıkmıştır. Şemsiye sayısında görülen farklılıkların, tohum materyali, farklı lokasyonlar ve bitki sıklığının neden olabileceği düşünülmektedir.

\section{Bin Tane A ̆grırlı̆̆ı}

Elde edilen veriler istatistiki olarak değerlendirildiğinde, $\quad 1000$ tane ağırlı̆̆1 bakımından ortalamalar arasında $\% 1$ düzeyinde önemli farklılık gözlenmiştir. Anason (Pimpinella anisum L.) hatlarının bin tane ağırlığına ait ortalamalar ve önemlilik grupları Çizelge 5'de gösterilmiştir. Denemede yer alan anason hatlarının bin tane ağırlıkları 3.00-4.00 g arasında değiştiği görülmektedir. En yüksek değere sahip grubu Madrid-213, Çavdır-10, Suriye-49 ve Tefenni-177 kökenli hatlar Suriye-51, Özel sektör-146, Özel sektör-150 ve Mısır-168 hatları en düşük değerlere sahip grubu oluşturmuşlardır (Çizelge 4).

Bornova ekolojik koşullarında; Bayram (1992), Boztaş (2018), Sönmez (2018) yürüttükleri araştırmalarda bin tane ağırlığının sırasıyla 2.30$2.65 \mathrm{~g} ; 2.60-3.5 \mathrm{~g} ; 2.20-3.10 \mathrm{~g}$ arasında değiștiğini bildirmişlerdir. Ankara ekolojik koşullarında; Demirayak (2002) bin tane ağırlığını 4.22$5.62 \mathrm{~g}$, İpek vd. (2004), bin tane ağırlı̆̆ını 4.01-5.46 g arasında değiştiğini belirtmişlerdir. Özel ve Demirbilek (2000), Harran Ovası kuru koşullarında bin tane ağırlığını 1.17-2.95 g, Şahin (2013), Konya'nın Göller Yöresi Havzası koşullarında bin tane ağırlığını 1.90-2.70 g, Akkan (2016), Edirne ekolojik koşullarında bin tane ağırlığını 5.59-9.11 g arasında değiştiğini ifade etmişlerdir.

Bornova koşullarında yürüttügüümüz araştırma sonucunda bin tane ağırlığına ilişkin elde ettiğimiz bulgular (3.00-4.00 g); Bayram (1992), Boztaş (2018), Özel ve Demirbilek (2000), Şahin (2013)' in sonuçlarından daha yüksek, Demirayak (2002), İpek ve ark. (2004) ve Akkan (2016)'ın bulgularından daha düşük çıkmıştır. Sönmez (2018)'in belirttiği alt sınır 
değerinden daha yüksek, üst sınır değerlerine benzerlik göstermektedir. Bin tane ağırlıklarında görülen farklılıkların; tohum materyali, ekim zamanı, ekim sıklığı, yağış miktarı, sıcaklık ve gübre uygulamalarından kaynaklanabileceği düşünülmektedir.

\section{Biyolojik Verim}

Bornova ekolojik koşullarında yetiştirilen anason hatlarının biyolojik verim açısından ortalamaları arasında istatistiksel olarak \%5 düzeyinde olarak önemli farklılık bulunmuştur. Hatlar arasındaki biyolojik verim değerleri 184.50-270.25 kg/da arasında değişmiştir. En düşük biyolojik verime sahip grubu Çavdır-10, Suriye-49, Fethiye-85, Özel Sektör-146 ve Özel Sektör-150, en yüksek biyolojik verime sahip grubu ise Çeşme-31, Suriye-51, Özel Sektör-164, Misır-168, Tefenni-177 ve Madrid-213 hatları oluşturmuşlardır.

Biyolojik verim ile ilgili yapılan daha önceki çalışmalarda; Bornova koşullarında, Bayram (1992) 121.10-142.20 kg/da, Boztaş (2018) 130.50-180.50 kg/da, Sönmez (2018) 133.30$141.00 \mathrm{~kg} / \mathrm{da}$ arasında değiştiğini bildirmişlerdir. Bizim elde ettiğimiz bulgular bu değerlerden daha yüksek bulunmuştur. Ankara ekolojik koşullarında; İpek ve ark (2004) biyolojik verimi 190.30-352.70 kg/da, Demirayak (2002) 190.50$350.50 \mathrm{~kg} / \mathrm{da}$ arasında değiştiğini belirtmişlerdir. $\mathrm{Bu}$ sonuçlar elde ettiğimiz değerler ile uyum göstermektedir.

\section{Tohum Verimi}

Bornova ekolojik koşullarında yetiştirilen anason hatlarının tohum verim açısından ortalamaları arasında farklılık istatistiki olarak önemsiz bulunmuştur. Çalışmada anason hatlarının tohum verimine ait ortalamaların verildiği Çizelge 5'i incelediğimizde, tohum verimi 77.62-110.82 $\mathrm{kg} /$ da gibi oldukça geniş bir aralıkta değiştiği görülmektedir. Sirasıyla Özel sektör-164 (110.82 kg/da), Özel sektör-150 (106.17 kg/da) ve Çeşme-31 (104.97 kg/da) hatları en yüksek verime sahip olmuşlardır. En düşük tohum verimine ise sirasıyla Özel sektör-146 (77.62 $\mathrm{kg} / \mathrm{da})$, Çavdır-10 (87.10 kg/da) ve Madrid-213 $(89.50 \mathrm{~kg} / \mathrm{da})$ hatlarında elde edilmiştir. Hatlara ilişkin genel ortalama tohum veriminin ise 97.10 $\mathrm{kg} / \mathrm{da}$ olduğu görülmektedir.

Bornova ekolojik koşullarında tohum verimini; Bayram (1992) 42.60-49.10 kg/da, Boztaş (2018) 50.85-69.47 kg/da, Sönmez (2018) 62.10$86.20 \mathrm{~kg} / \mathrm{da}$ arasında değiştiğini bildirmişlerdir. İpek vd. (2004) Ankara ekolojik koşullarında bazı anason popülasyonlarının adaptasyonu ile ilgili yapmış oldukları araştırmada, tohum verimini 48.80-81.80 kg/da; Akkan (2016) Edirne ekolojik koşullarında anasonda farklı ekim zamanlarının verim ve kalite üzerinde etkisini belirlemek amacıyla yaptığı araştırmada 46.47-94.26 kg/da olarak saptamışlardır. Bütün (2016) Tekirdağ koşullarında farklı tohum miktarlar1 (1-2-3 kg/da) ve sira arası mesafelerin $(15-30 \mathrm{~cm})$ bazı anason popülasyonlarının (Denizli, Çeşme, Burdur) tarımsal ve kalite özellikleri üzerine etkisini belirlemek için yaptığ1 çalışmada, tohum verimini 55.26-93.81 $\mathrm{kg} / \mathrm{da}$ olarak kaydetmişlerdir. Araştırma sonucu tohum verimine ait elde ettiğimiz bulgular bu sonuçlardan daha yüksek olarak elde edilmiştir. Tohum veriminde görülen bu farklıların ekim 
zamanı, iklim koşulları, toprak özellikleri, tohum materyali ve yetiştirme teknikleri gibi farklı uygulamalardan kaynaklandığı düşünülmektedir. Doğramacı ve Arabacı (2010), Aydın koşullarında organik ve inorganik gübre uygulamalarının anason çeşit ve ekotiplerinin verim ve verim öğeleri üzerine etkisini araştırdıkları çalışmada, tohum verimini 30.40-114.50 kg/da, Özel ve ark. (2014), Şanlıurfa da yürüttüğü denemede tohum verimini $95.80-147 \mathrm{~kg} / \mathrm{da}$ olarak belirlemişlerdir. $\mathrm{Bu}$ sonuçlar ise bulgularımızla paralellik göstermiştir.

\section{Hasat İndeksi}

Bornova ekolojik koşullarında yetiştirilen anason hatlarının hasat indeksi açısından ortalamaları arasında istatistiki olarak önemli bir farklılık bulunmamıştır. Hasat indeksi oranları \% 36.50\% 47.50 arasında değişim göstermiştir (Çizelge 4). Hatlara ilişkin genel ortalama hasat indeksi ise $\% 41.70$ olduğu görülmektedir.

\section{Bornova ekolojik koşullarında; Bayram}

(1992), farklı sıra arası ve tohumluk miktarı uygulamalarının anason ekotiplerinin bazı verim ve kalite özellikleri üzerine olan etkilerini incelediği araştırmada hasat indeksinin \% 36.30$\%$ 40.70, farklı gübre dozları ve ekim yöntemi uygulamalarının etkisini araştırdığı denemede ise hasat indeksinin \% 38.60-42.60, Boztaş (2018) Geliştirilmiş anason hatlarında verim ve kalite özelliklerini araştırdığı çalışmada hasat indeksinin \% 31.00-\% 42.24 arasında değiştiğini tespit etmiş̧lerdir. Araştırmada hasat indeksine ait elde ettiğimiz bulgular Bayram (1992) ve Boztaş (2018)'ın bildirdikleri alt sınır değerleri ile uyumlu, üst sınır değerlerinden daha yüksek bulunmuştur.

Uygun ekim zamanlarının belirlenmesi amacıyla; Aksin (2000), Diyarbakır koşullarında yürüttüğü çalışmada hasat indeksini \%12.6728.98, Koşar (2002) Harran ovası koşullarında hasat indeksinin \% $\quad 13.3-\% \quad 29.3$ arasinda değiştiğini bildirmişlerdir. Aksin (2000) ve Koşar (2002)'ın hasat indeksine ait bulguları araştırma sonuçlarımızdan daha düşük çıkmıştır.

\section{Uçucu Yağ Oranı}

Bornova ekolojik koşullarında yetiştirilen anason hatlarının uçucu yağ açısından ortalamaları arasında istatistiki olarak \%5 düzeyinde önemli farklılık bulunmuştur. Uçucu yăg oranının \%2-3 arasında değiştiği ve üç grubun oluştuğu görülmektedir. Çavdır-10 ve Tefenni-177 hatları hariç incelenene tüm hatlar en yüksek uçucu yağ oranına sahip grubu, Çavdır-10, Çeşme-31, Suriye-49, Suriye-51, Fethiye-85, Özel Sektör-150, Özel Sektör-164, Misır-168 ve Tefenni-177 hatlar en düşük uçucu yağ oranına sahip grubu oluşturmuştur (Çizelge 5).

Anasonda uçucu yăg oranına ilişkin elde ettiğimiz sonuçlar; Sönmez (2018) \%2.40-3.60, İpek ve ark. (2004) \%2.09-3.11, Demirayak (2002) \%2.10-3.78, Y1ldirım (2010) \%2.403.90; Şahin (2013), \%2.45-4.10, Özel ve ark. (2014), \%2.75-4.64 arasında değiștiğini belirtmişlerdir. Bu çalışma sonucu elde ettiğimiz uçucu yağ bulguları; Sönmez (2018), İpek ve ark. (2004), Demirayak (2002), Yıldırım (2010), Şahin (2013), Özel ve ark. (2014)'nın alt değer sınırlar ile uyumlu, üst sınır değerlerinden düşük bulunmuştur. Uçucu yağ oranında görülen bu farklılıklara; iklim, gübreleme, sulama ve 
kullanılan tohumluk materyalin özelliklerinin neden olabileceği söylenebilir.

\section{SONUÇ ve ÖNERÍLER}

Anasonun en önemli kısmı, meyveleri ve tohumlarından elde edilen uçucu yağ oranıdır. Sonuçlar genel olarak değerlendirildiğinde, istatistiki olarak fark çıkmamasına rağmen tohum verimi bakımından Özel Sektör-164, Özel sektör-150 ve Çeşme-31 hatları ön plana çıkmışlardır. Uçucu yağ oranı bakımından ise Madrid-213 ve Özel sektör-146 hatları en yüksek oranlara sahip hatlar olarak belirlenmişlerdir. Ancak Çeşme-31 ve Suriye-51 hatları uçucu yağ oranı bakımından adı geçen iki hatla aynı istatistik grupta yer almıştır. Yapılan bu çalışma sonucunda, Bornova ekolojik koşullarında tohum verimi ve uçucu yağ oranı parametreleri açısından ön plana çıkan hatların, anason çeşit geliştirme çalışmalarında materyal olarak kullanılabilecekleri düşünülmektedir.

\section{TEŞEKKÜRLER}

Bu makale, 2018-ZRF-018 no'lu Ege Üniversitesi BAP (Yüksek Lisans Tez) projesinden özetlenmiştir. Tez projeme maddi destek veren Ege Üniversitesi Bilimsel Araştırma Projeleri Komisyonu'na teşekkür ederim.

\section{AÇIKLAMA}

Çalışmanın yürütülmesi ve sonuçların yazılması esnasında araştırma ve yayın etiğine uyulmuştur. Herhangi bir "Çıkar Çatışması" bulunmamaktadır. Makalede yazarlar eşit oranda katkı sağlamıştır.

\section{KAYNAKÇA}

Açıkgöz, N., İlker, E. ve Gökçöl, A. 2004. Biyolojik Araştırmaların Bilgisayarda Değerlendirilmeleri. ISBN: 973-483-6078 E.Ü. Tohum Teknolojisi Araştırma ve Uygulama Merkezi Yayın No:2. İzmir.

Akgül, A. 1993. Baharat Bilim ve Teknolojisi. Gıda Teknolojisi Derneği Yayınları No.15. Ankara.

Akkan, E. 2016. Edirne Koşullarında Anason (Pimpinella anisum L.) Farklı Ekim Zamanlarının Verim ve Kaliteye Etkisi. Yüksek Lisans Tezi. Namık Kemal Üniversitesi, Fen Bil. Ens. Tarla Bitkileri Anabilim Dalı - Tekirdağ.

Aksin, N. 2000. Farklı Anason (Pimpinella anisum L.) Ekotiplerinin Diyarbakır Koşullarında Uygun Ekim Zamanlarının Belirlenmesi Üzerine Bir Çalışma. Yüksek Lisans Tezi. Diyarbakır Ü. Fen Bil. Ens. Tarla Bitkileri Anabilim Dal1- Diyarbakır.

Anonim, 2017. Bornova Meteroloji İstasyonu, Izmir.

Arslan, N., Gürbüz, B. Gümüşçü, A. 1999. Farklı Orijinli Anason (Pimpinella anisum L.) Populasyonlarında Verim ve Verim Özelliklerinin Araştırılması. Tarla Bitkileri Merkez Araştırma Enstitüsü Dergisi. 8:12.

Bayram, E. 1992, Türkiye kültür anasonları (Pimpinella anisum L.) üzerinde agronomik ve teknolojik araştırmalar. Doktora Tezi. E.Ü. Zir. Fak. Fen Bilimleri Enstitüsü. Tarla Bitkileri Anabilim Dalı Bornova - İzmir. 
Bayram, E., 2019. Tohum Tohumculuk ve Teknolojileri 2. Tibbi ve aromatik bitkilerde tohumluk üretimi ve sertifikasyonu -Anasonda tohumluk üretimi ve sertifikasyonu. BİSAB (Bitki Islahçıları Alt Birliği), 1. Basım, 2. Cilt, Ankara. s. 1077-1098.

Blumenthal, M. 1999. The Complete German Commission E Monographs, therapeutic guide to herbal medicines. American Botanical Council, Austin, Texas.

Boztaş, G. 2018. Geliştirilmiş anason hatlarında verim ve kaliteyi etkileyen agronomik, morfolojik ve fizyolojik farklılıkların belirlenmesi üzerinde araştırmalar. Yüksek Lisans Tezi. E.Ü. Zir. Fak. Fen Bilimleri Enstitüsü. Tarla Bitkileri Anabilim Dalı Bornova - İzmir.

Bütün, Y. 2016. Farklı tohumluk miktarı ve sira arası mesafelerinin bazın anason (Pimpinella anisum L.) popülasyonlarının tarımsal ve kalite özelliklerine etkisi. Yüksek Lisans Tezi. Namık Kemal Üniversitesi Fen. Bil. Ens. Tarla Bitkileri Anabilim Dalı - Tekirdağ

Ceylan, A. 1997. Tibbi Bitkiler II, E.Ü., Ziraat Fakültesi Yayınları No:481, 188s. İzmir.

Dağıstanlıŏ̆lu, C. Uçgun, K., Kaymak, S. ve Atasay, A. 2009. Göller Bölgesi'nde Seçilmiş Bazı Anason Populasyonlarının Verim ve Kalite Özellikleri Üzerine Araştırmalar. Selçuk Üni. Selçuk Tarım ve Gıda Bilimleri Dergisi. 23 (47):38-43.

Demirayak, Ş. 2002. Bazı Anason (Pimpinella anisum L.) Populasyonlarında Farklı Ekim
Zamanlarının Verim ve Verim Öğeleri Üzerine Etkileri. Yüksek Lisans Tezi. Ankara Uni. Fen Bil. Ens. Tarla Bitkileri Anabilim Dal1-Ankara.

Doğan, Ö., Kara N., Tonguç, M. 2018. Anason populasyonlarında verim ve kalite ile genetik ilişkilerin araştırılması. Black Sea Journal of Agriculture 1(4): 110-116.

Doğramac1, S. ve Arabac1, O. 2010. Organik ve İnorganik Gübre Uygulamalarının Anason (Pimpinella anisum L.) Çeşit ve Ekotiplerinin Verim ve Verim Öğelerinin Üzerine Etkisi. Adnan Menderes Uni. Zir. Fak. Dergisi 7 (2):103-109.

Gülçin, I., Oktay, M., Kireçci, E., Küfrevioğlu, Ö. I. 2003. Screening of antioxidant and antimicrobial activities of anise (Pimpinella anisum L.) seed extracts. Food Chemistry 83 (3): 371-382.

İpek, A., Demirayak, Ş., Gürbüz, B. 2004. A Study on the Adaptation of Some Anise (Pimpinella anisum L.) Population to Ankara Conditions. Tarım Bilimleri Dergisi. 10 (2): 202-205.

Koşar, I. G. 2002. Harran Ovası koşullarında anason (Pimpinella anisum L.)'da uygun ekim zamanlarının belirlenmesi. Yüksek Lisans Tezi. Harran Üniversitesi. Fen Bil. Ens. Tarla Bitkileri Anabilim Dal1Şanlıurfa

Orav, A., Raal, A., and Arak, E.. 2008. Essential Oil Composition of Pimpinella anisum L. Fruits from Various European Countries. Natural Product Research, Volume 22 (3); 227-232. 
Özcan, M. M., and Chalchat, J. C. 2006. Chemical composition and antifungal effect of anise (Pimpinella anisum L.) fruit oil at ripening stage. Annals of Microbiology 56(4): 353358.

Özel, A., Demirbilek, T., 2000. Harran Ovas1 Kuru Koşullarında Bazı Tek Yı1lık Baharat Bitkilerinin Verim ve Bazı Agronomik Özelliklerinin Belirlenmesi. Harran Üniversitesi Ziraat Fakültesi Dergisi. 4:2133.

Özel, A., Koşar, I.G., Erden, K., ve Demirel, U. 2014. Determination of the Optimum Seed Amount and Inter-Row Spacing for the Seed and Essential Oil Yield of Aniseed (Pimpinella anisum L.). Journal of Essential Oil Bearing Plants 17(3):405414.

Şahin, B. 2013. Farklı Ekim Zamanlarında Yetiştirilen Bazı Tıbbi Bitkilerin Verim ve Kalite Özelliklerinin Belirlenmesi. Yüksek Lisans Tezi. Selçuk Üni. Fen Bil. Enst. Tarla Bitkileri Anabilim Dalı - Konya.

Shojaii, A., Fard, M.A. 2012. Review of pharmacological properties and chemical constituents of Pimpinella anisum. Int. Sch. Res. Netw.-ISRN Pharm. 2012, 1-8.

Sönmez Ç. 2018. Effect of Phosphorus Fertilizer on Some Yield Components and Quality of Different Anise (Pimpinella anisum L.) Population. Turkish Journal of Fields Crops 23(2):100-106.

Tepe, B., Akpulat, A. H., Sokmen, M., Daferera, D., Yumrutas, O., Aydin, E., Polissiou, M., Sokmen, A. 2006. Screening of the antioxidative and antimicrobial properties of the essential oil of Pimpinella anisetum and Pimpinella flabellifolia from Turkey. Food Chemistry. 97(4): 719-724.

Tirapelli, C.R., Andrade, C.R., Cassano, A.O., De Souza, F.A., Ambrosio, S.R., Costa, F.B. and Oliveria, A. M. 2007. Antispasmodic and relaxant effects of the hydroalcoholic extract of Pimpinella anisum (Apiaceae) on rat anococcygeous smooth muscle. Journal of Ethnopharmacology 110 (1): 23-29.

Tunç, I., Sahinkaya, S. 1998. Sensitivity Of Two Greenhouse Pests to Vapours of Essential Oils. Entomologia Experimentalis Et Applicata 86(2): 183-187.

Y1ldırım, V. 2010. Türk Anason Genotiplerinin (Pimpinella anisum L.) Tekirdağ Koşullarında Tohum Verimi ve Bazı Bitkisel Özellikleri Üzerinde Bir Çalışma. Yüksek Lisans Tezi. Namık Kemal Ü. Fen Bil. Ens. Tarla Bitkileri Anabilim Dalı Tekirdağ.

Wichtl,M.1971.Diepharmakogostich-chemisehe Untersuchung und Wertbestimmung von Droge und galenischen Präparaten. Methoden der Analyse in der Chemie Band 12. Frankfurt and Main. 